Available online at http://journal.stkip-andi-matappa.ac.id/index.php/histogram/index

Histogram : Jurnal Pendidikan Matematika 2 (2), 2018, 82-96

\title{
PEMBELAJARAN SCIENTIFIC APPROACH DAN REALISTIK TERHADAP PRESTASI DAN MINAT DITINJAU DARI KEMANDIRIAN
}

\author{
Annis Deshinta Ayuningtyas ${ }^{1}$, Dafid Slamet Setiana ${ }^{2}$ \\ Universitas Sarjanawiyata Tamansiswa, Yogyakarta ${ }^{1,2}$ \\ * Corresponding Author. Email: annis_deshinta@yahoo.com \\ Received: 12 March 2018; Revised: 21 September 2018; Accepted: 27 September 2018
}

\section{ABSTRAK}

Tujuan penelitian ini untuk mengetahui: (1) Manakah yang memberikan prestasi dan minat belajar lebih baik, pembelajaran scientific approach, pendekatan realistik atau pembelajaran langsung. (2) Manakah yang mempunyai prestasi dan minat belajar lebih baik antara mahasiswa yang mempunyai kemandirian belajar tinggi, sedang, atau rendah. (3) Pada masing-masing tingkatan kemandirian belajar, manakah yang memberikan prestasi dan minat belajar lebih baik antara pembelajaran scientific approach atau pembelajaran langsung. Penelitian ini termasuk penelitian eksperimental semu dengan desain factorial 3x3. Banyak sampel 119 mahasiswa. Instrumen pengumpulan data adalah angket kemandirian belajar dan tes prestasi belajar. Analisis tes prestasi menggunakan analisis variansi dua jalan dengan sel tak sama. Dari hasil analisis diperoleh kesimpulan bahwa: (1) Pembelajaran dengan pendekatan pembelajaran scientifik menghasilkan prestasi belajar yang lebih baik jika dibandingkan dengan pendekatan pembelajaran langsung. (2) Pembelajaran dengan pendekatan realistik menghasilkan prestasi belajar yang lebih baik jika dibandingkan dengan pendekatan pembelajaran langsung. (3) Kemandirian belajar berpengaruh terhadap prestasi belajar. Hal ini berarti bahwa mahasiswa yang memiliki kemandirian belajar tinggi, kemandirian belajar sedang, dan kemandirian belajar rendah memiliki prestasi belajar yang berbeda. (4) Tidak ada interaksi antara pendekatan pembelajaran dengan kemandirian belajar terhadap prestasi belajar. (5) Tidak ada interaksi antara pendekatan pembelajaran dengan kemandirian belajar matematika terhadap minat belajar matematika

Kata Kunci: prestasi, minat, kemandirian, scientific approach, realistik

How to Cite: Ayuningtyas, D, A., Setiana, S, D. (2018). Pembelajaran Scientific Approach Dan Realistik Terhadap Prestasi Dan Minat Ditinjau Dari Kemandirian. Histogram: Jurnal Pendidikan Matematika, 2(2), 82-96. doi: http://dx.doi.org/10.31100/histogram.v2i2.116

Permalink/DOI:

http://dx.doi.org/10.31100/histogram.v2i2.116

\section{PENDAHULUAN}

Pendidikan merupakan hal yang sangat penting dalam kehidupan. Pendidikan diperlukan manusia sepanjang hayat. Selain itu, pendidikan merupakan upaya untuk meningkatkan kualitas Sumber Daya Manusia (SDM) baik fisik, mental, dan spiritual. Oleh karena itu pendidikan harus ditumbuhkembangkan secara sistematis sehingga tercipta suatu sistem pendidikan yang dapat menghasilkan SDM yang berkualitas. Agar dapat menghasilkan SDM yang berkualitas diperlukan juga suatu sistem pendidikan yang berkualitas. Pemerintah selalu berusaha meningkatkan mutu pendidikan nasional melalui perubahan sistem pendidikan nasional dengan berbagai macam komponen yang terdapat di

This is open access article under the CC-BY-SA-license.

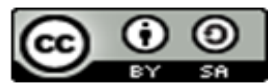




\section{Histogram: Jurnal Pendidikan Matematika, 2 (2), 2018 - 83 Annis Deshinta Ayuningtyas, Dafid Slamet Setiana}

dalamnya. Salah satu bentuk perubahan tersebut adalah perbaikan kurikulum antara lain diberlakukannya kurikulum 2015 yang diselaraskan dengan KKNI.

Kerangka Kualifikasi Nasional Indonesia (KKNI), lulusan setara S1 harus memiliki beberapa kompetensi antara lain : (1) Mampu mengaplikasikan bidang keahliannya dan memanfaatkan IPTEKS pada bidangnya dalam penyelesaian masalah serta mampu beradaptasi terhadap situasi yang dihadapi, (2) Menguasai konsep teoritis bidang pengetahuan tertentu secara umum dan konsep teoritis bagian khusus dalam bidang pengetahuan tersebut secara mendalam serta mampu memformulasikan penyelesaian masalah prosedural, (3) Mampu mengambil keputusan yang tepat berdasarkan analisis informasi dan data, dan mampu memberikan petunjuk dalam memilih berbagai alternatif solusi secara mandiri dan kelompok, (4) Bertanggung jawab pada pekerjaan sendiri dan dapat diberi tanggung jawab atas pencapaian hasil kerja organisasi. Dengan berlakunya KKNI diharpakan pembelajaran berpusat pada mahasiswa, mahasiswa menjadi lebih aktif dan mandiri sehingga mampu menguasai konsep lebih mendalam yang pada akhirnya berpengaruh terhadap prestasi belajar mahasiswa.

Berdasarkan fakta yang ada di lapangan diketahui bahwa prestasi belajar mahasiswa belum maksimal. Hal ini terlihat masih banyak mahasiswa yang mengulang kuliah pada beberapa mata kuliah. Salah satu mata kuliah dengan banyak mahasiswa yang mengulang adalah mata kuliah program linear. Padahal mata kuliah matematika ekonomi merupakan mata kuliah yang cukup penting karena saat menjadi guru matematika di jenjang SMA/SMK lulusan prodi pendidikan matematika mengajar mengenai program linear. Selain itu, mata kuliah program linear menjadi syarat untuk mempelajari mata kuliah riset operasi.

Rendahnya prestasi belajar pada mata kuliah program linear disebabkan oleh berbagai faktor. Faktor yang mempengaruhi dari dalam diri mahasiswa antara lain: minat, motivasi, kemampuan awal, intelegensi, kemandirian belajar, kedisipilinan belajar, kreativitas belajar, gaya belajar, dan sebagainya. Salah satu faktor dari dalam diri mahasiswa adalah minat dan kemandirian belajar. Getsel (Anderson, 2009: 35), “ $A n$ interest is a disposition organized through experience which impels an individual to seek out particular objects, activities, understandings, skills, or goals for attention or acquisition". Minat merupakan suatu disposisi yang terorganisir melalui pengalaman yang mendorong seseorang untuk memperoleh objek khusus, aktivitas, pemahaman, dan keterampilan untuk tujuan perhatian atau pencapaian. Menurut Hurlock (2002: 116), minat Copyright (C) 2018, Histogram: Jurnal Pendidikan Matematika ISSN: 2549-6700 (print), ISSN 2549-6719 (online) 


\section{Histogram: Jurnal Pendidikan Matematika, 2 (2), 2018 - 84 Annis Deshinta Ayuningtyas, Dafid Slamet Setiana}

mempunyai dua aspek yaitu aspek kognitif dan aspek afektif. Aspek kognitif didasarkan atas konsep yang dikembangkan mahasiswa mengenai bidang yang berkaitan dengan minat yaitu rasa ingin tahu dan rasa kebutuhan yang dimiliki mahasiswa. Aspek afektif dinyatakan dalam sikap terhadap kegiatan yang ditimbulkan minat. Seperti halnya aspek kognitif, aspek afektif berkembang dari pengalaman pribadi dan dari sikap orang-orang yang ada dalam lingkungannya. Dalam hal ini aspek afektif cenderung pada sikap dan perasaan senang terhadap pengalaman yang dimiliki mahasiswa.

Secara struktural minat merupakan suatu elemen dalam diri individu baik bawaan maupun yang diperoleh lewat proses belajar, yang menyebabkan seseorang merasa mendapatkan manfaat terhadap suatu objek tertentu atau merasa yang berhubungan dengan objek atau pengetahuan. Collete \& Chiappetta (1994: 74) juga menyatakan "interest is defined as curiosity or fascination for an idea or event that engages attention". Minat didefinisikan sebagai keingintahuan atau daya tarik pada suatu pemikiran atau kejadian yang melibatkan perhatian.

Kemandirian meliputi perilaku mampu berinisiatif, mampu mengatasi masalah, mempunyai rasa percaya diri dan dapat melakukan sesuatu sendiri tanpa bantuan orang lain. Soesarsono (2004: 43-44) mengemukakan bahwa orang yang mempunyai inisiatif adalah orang yang tanggap, berpikir kritis, dan tidak segan memberikan saran yang baik kepada orang lain. Siswa yang mandiri adalah siswa yang bertanggung jawab, berinisiatif, memiliki keberanian, dan sanggup menerima resiko serta mampu menjadi guru bagi dirinya sendiri yang berarti siswa bisa mengatur kegiatan belajarnya sendiri (Yamin, 2007: 126). Belajar atas inisiatif sendiri dapat memusatkan perhatian siswa baik pada proses maupun hasil belajar. Siswa yang belajar atas inisiatif sendiri menjadi bebas, tidak tergantung, dan percaya pada diri sendiri. Apabila siswa belajar atas inisiatif sendiri maka dia memiliki kesempatan untuk menimbang-menimbang dan membuat keputusan, menentukan pilihan dan melakukan penilaian (Sri Rumini,dkk, 2006:109).

Adapun salah satu faktor yang berasal dari luar mahasiswa adalah pendekatan, metode, dan model pembelajaran yang digunakan. Upaya mengimplementasikan Kurikulum 2015 yang diselaraskan dengan KKNI diperlukan suatu pembelajaran dimana mahasiswa dituntut untuk mengamati, menalar, mencoba menyelesaikan serta membentuk jejraing antar konsep terkait dengan suatu permasalahan yang disajikan. Dengan demikian mahasiswa menjadi lebih aktif dan mandiri dalam pembelajaran. Hal ini sejalan dengan tuntutan Kurikulum 2013 yang diterapkan di sekolah dasar dan menengah dimana Copyright (c) 2018, Histogram: Jurnal Pendidikan Matematika ISSN: 2549-6700 (print), ISSN 2549-6719 (online) 


\section{Histogram: Jurnal Pendidikan Matematika, 2 (2), 2018 - 85 \\ Annis Deshinta Ayuningtyas, Dafid Slamet Setiana}

kurikulum tersebut menekankan pada dimensi pedagogik modern dalam pembelajaran yaitu menggunkan pendekatan ilmiah. Pendekatan ilmiah (scientific approach) dalam pembelajaran sebagaimana dimaksud meliputi mengamati, menanya, menalar, mencoba, membentuk jejaring untuk semua mata pelajaran. Penguatan terhadap pendekatan ilmiah (scinetific approach) pada mahasiswa calon guru merupakan hal yang sangat penting untuk dilakukan. Hasil dari penguatan tentang pendekatan ilmiah ini, mahasiswa calon guru diharapkan memiliki bekal untuk dapat menerapkan pendekatan tersebut dalam pembelajaran di kelas ketika mahasiswa tersebut menjadi guru. Selain itu, proses pembelajaran sebaiknya dilakukan melalui proses eksplorasi, elaborasi, dan konfirmasi. Jika ditinjau dari sudut pandang Pendidikan Matematika Realistik ketiga macam proses tersebut merupakan karakteristik dari Pendidikan Matematika Realistik. Oleh karena itu, bisa dikatakan bahwa penerapan pendekatan Pendidikan Matematika Realistik untuk pembelajaran matematika sesuai dengan kurikulum.

Berdasarkan uraian di atas, peneliti ingin menerapkan scientific approach dan pendekatan realistik pada pembelajaran matematika calon guru untuk mengetahui pengaruhnya terhadap prestasi dan minat belajar dengan memperhatikan kemandirian belajar mahasiswa.

\section{METODE PENELITIAN}

Jenis penelitian ini adalah penelitian eksperimental semu (quasi exsperimental research). Subyek dalam penelitian ini adalah mahasiswa prodi pendidikan matematika semester III tahun ajaran 2016/2017.

\section{A. Rancangan Penelitian}

Penelitian ini menggunakan rancangan faktorial 3x3, dengan maksud untuk mengetahui pengaruh variabel bebas terhadap variabel terikat.

Tabel 1. Rancangan Penelitian

\begin{tabular}{lllllll}
\hline \multicolumn{1}{c}{ Kemandirian Belajar } & $\begin{array}{l}\text { Tinggi } \\
\left(\mathrm{b}_{1}\right)\end{array}$ & $\begin{array}{l}\text { Sedang } \\
\left(\mathrm{b}_{2}\right)\end{array}$ & $\begin{array}{l}\text { Rendah } \\
\left(\mathrm{b}_{3}\right)\end{array}$ & \\
Pembelajaran & $\left(\mathrm{a}_{1} \mathrm{~b}_{1}\right)_{1}$ & $\left(\mathrm{a}_{1} \mathrm{~b}_{1}\right)_{2}$ & $\left(\mathrm{a}_{1} \mathrm{~b}_{2}\right)_{1}$ & $\left(\mathrm{a}_{1} \mathrm{~b}_{2}\right)_{2}$ & $\left(\mathrm{a}_{1} \mathrm{~b}_{3}\right)_{1}$ & $\left(\mathrm{a}_{1} \mathrm{~b}_{3}\right)_{2}$ \\
\hline Scientific Approach $\left(\mathrm{a}_{1}\right)$ & $\left(\mathrm{a}_{2} \mathrm{~b}_{1}\right)_{1}$ & $\left(\mathrm{a}_{2} \mathrm{~b}_{1}\right)_{2}$ & $\left(\mathrm{a}_{2} \mathrm{~b}_{2}\right)_{1}$ & $\left(\mathrm{a}_{2} \mathrm{~b}_{2}\right)_{2}$ & $\left(\mathrm{a}_{2} \mathrm{~b}_{3}\right)_{1}$ & $\left(\mathrm{a}_{2} \mathrm{~b}_{3}\right)_{2}$ \\
\hline Realistik $\left(\mathrm{a}_{2}\right)$ & $\left(\mathrm{a}_{3} \mathrm{~b}_{1}\right)_{1}$ & $\left(\mathrm{a}_{3} \mathrm{~b}_{1}\right)_{2}$ & $\left(\mathrm{a}_{3} \mathrm{~b}_{2}\right)_{1}$ & $\left(\mathrm{a}_{3} \mathrm{~b}_{2}\right)_{2}$ & $\left(\mathrm{a}_{3} \mathrm{~b}_{3}\right)_{1}$ & $\left(\mathrm{a}_{3} \mathrm{~b}_{3}\right)_{2}$ \\
\hline Langsung & & & & &
\end{tabular}

(Sumber: Data Primer, Tahun: 2017) 


\section{Histogram: Jurnal Pendidikan Matematika, 2 (2), 2018 - 86 \\ Annis Deshinta Ayuningtyas, Dafid Slamet Setiana}

\section{B. Teknik Pengumpulan Data}

1. Teknik Dokumentasi

Budiyono (2003:54) berpendapat bahwa dokumentasi adalah cara pengumpulan data dengan melihatnya dalam dokumen-dokumen yang telah ada.

\section{Teknik Tes}

Tes adalah cara pengumpulan data yang menghadapkan sejumlah pertanyaanpertanyaan atau suruhan-suruhan terhadap subyek penelitian (Budiyono, 2003 : 54). Teknik tes dilakukan untuk mengumpulkan data prestasi belajar.

\section{Teknik Angket}

Teknik angket adalah cara pengumpulan data melalui pengajuan pertanyaanpertanyaan tertulis kepada subjek penelitian, responden, atau sumber data dan jawabannya diberikan secara tertulis (Budiyono, 2003: 47). Teknik angket dilakukan untuk mengumpulkan data mengenai minat dan kemandirian belajar.

\section{Teknik Analisis Data}

1. Uji Keseimbangan

Sebelum peneliti memberi perlakuan, terlebih dahulu menguji kesamaan rerata dari 2 kelompok eksperimen dan 1 kelompok kontrol. Uji ini bertujuan untuk mengetahui apakah ketiga kelompok tersebut dalam keadaan seimbang. Uji keseimbangan yang akan dilakukan adalah dengan menggunakan ANAVA satu jalan dengan sel tak sama. Sebelum dilakukan ANAVA perlu dilakukan uji prasyarat untuk menggunakan ANAVA yaitu uji normalitas populasi dan uji homogenitas variansi.

Setelah dilakukan uji prasyarat untuk ANAVA maka selanjutnya dilakukan ANAVA satu jalan dengan sel tak sama untuk menguji keseimbangan. (Budiyono, 2009:195-198)

\section{Uji Hipotesis}

Uji hipotesis yang digunakan adalah uji analisis variansi (ANAVA). Sebelum dilakukan analisis variansi terlebih dahulu harus diuji prasyarat uji analisis variansi yaitu uji normalitas populasi dan uji homogenitas variansi. (Budiyono, 2009: 228-234)

\section{Uji Lanjut Pasca ANAVA}

Komparasi ganda pasca anava adalah tindak lanjut dari analisis variansi apabila hasil analisis variansi tersebut menunjukkan bahwa hipotesis nol ditolak. Untuk uji lanjut pasca anava digunakan metode Scheffe' karena metode tersebut akan menghasilkan beda rerata dengan tingkat signifikan yang kecil. (Budiyono, 2009: 215-216). ISSN: 2549-6700 (print), ISSN 2549-6719 (online) 


\section{HASIL DAN PEMBAHASAN}

\section{A. Hasil Penelitian}

1. Deskripsi Data

a. Data Prestasi Awal

Untuk mengetahui apakah kelompok eksperimen 1, kelompok eksperimen 2 dan kelompok kontrol seimbang atau mempunyai kemampuan awal yang sama sebelum eksperimen dilakukan perlu dilakukan uji keseimbangan. Secara statistik uji keseimbangan dilakukan untuk mengetahui apakah terdapat perbedaan rataan yang berarti dari ketiga kelompok sampel. Statistik uji yang digunakan adalah analisis variansi satu jalan. Data yang digunakan untuk uji keseimbangan adalah nilai ujian tengah semester gasal dari tiga kelas. Sebelum dilakukan uji keseimbangan, terlebih dahulu dilakukan uji prasyarat untuk analisis variansi satu jalan sebagai berikut:

1) Uji Normalitas

Uji normalitas dilakukan dengan tujuan untuk mengetahui apakah sampel berasal dari populasi yang berdistribusi normal atau tidak. Uji normalitas dilakukan pada masingmasing kelompok data yaitu kelompok eksperimen 1 (Scientific), kelompok eksperimen 2 (PMRI), dan kelompok kontrol (pembelajaran langsung). Rangkuman hasil uji normalitas pada setiap kelompok eksperimen disajikan berikut ini:

Tabel 2. Hasil Uji Normalitas Prestasi Awal

\begin{tabular}{|c|c|c|c|c|}
\hline Kelompok & Sig & $\mathbf{A}$ & $\begin{array}{l}\text { Keputusan } \\
\text { Uji }\end{array}$ & Kesimpulan \\
\hline $\begin{array}{l}\text { Eksperimen } \\
\text { (Scientific) }\end{array}$ & 0,815 & 0,05 & $H_{0}$ diterima & Berdistribusi Normal \\
\hline $\begin{array}{l}\text { Eksperimen } \\
\text { (PMRI) }\end{array}$ & 0,649 & 0,05 & $H_{0}$ diterima & Berdistribusi Normal \\
\hline Kontrol (Langsung) & 0,838 & 0,05 & $H_{0}$ diterima & Berdistribusi Normal \\
\hline
\end{tabular}

(Sumber: Data Primer, Tahun: 2017)

Berdasarkan keputusan uji tersebut, maka dapat disimpulkan bahwa data pada setiap sampel berasal dari populasi yang berdistribusi normal.

2) Uji Homogenitas Variansi

Uji homogenitas variansi dilakukan dengan tujuan untuk mengetahui apakah populasi mempunyai variansi yang sama. Uji homogenitas variansi dilakukan pada ketiga kelompok kelas penelitian. Berikut ini disajikan rangkuman hasil uji homogenitas variansi pada ketiga kelompok kelas penelitian: 
Histogram: Jurnal Pendidikan Matematika, 2 (2), 2018 - 88

Annis Deshinta Ayuningtyas, Dafid Slamet Setiana

Tabel 3. Rangkuman Hasil Uji Homogenitas Variansi Prestasi

\begin{tabular}{lllll}
\hline Kelompok Kelas & Sig & $\boldsymbol{\alpha}$ & $\begin{array}{l}\text { Keputusan } \\
\text { Uji }\end{array}$ & Kesimpulan \\
\hline $\begin{array}{l}\text { Eksperimen 1 (Scientific), eksperimen } \\
\text { 2 (PMRI), dan kontrol (langsung) }\end{array}$ & 0,714 & 0,05 & $H_{0}$ diterima & Variansi \\
Homogen
\end{tabular}

(Sumber: Data Primer, Tahun: 2017)

Berdasarkan keputusan uji tersebut, maka dapat disimpulkan bahwa ketiga kelompok mempunyai variansi yang homogen.

3) Uji Keseimbangan

Uji keseimbangan dilakukan untuk mengetahui apakah setiap kelas sudah dalam keadaan yang sama atau seimbang. Uji keseimbangan yang dilakukan menggunakan anava satu jalan dengan sel tak sama. Berikut ini adalah rangkuman hasil anava satu jalan dengan sel tak sama:

Tabel 4. Rangkuman Hasil Uji Keseimbangan

\begin{tabular}{llll}
\hline Kelompok Kelas & Sig & A & $\begin{array}{l}\text { Keputusan } \\
\text { Uji }\end{array}$ \\
\hline $\begin{array}{l}\text { Eksperimen 1 (Scientific), eksperimen 2 (PMRI), dan } \\
\text { kontrol (langsung) }\end{array}$ & 0,550 & 0,05 & $H_{0}$ diterima \\
\hline
\end{tabular}

(Sumber: Data Primer, Tahun: 2017)

Berdasarkan Tabel 4 diketahui bahwa $H_{0}$ diterima, berdasarkan keputusan uji tersebut, maka dapat disimpulkan bahwa ketiga kelompok dalam keadaan seimbang atau memiliki kemampuan awal sama.

2. Uji Hipotesis

a. Uji Prasyarat Analisis

1) Uji Normalitas

Uji normalitas populasi bertujuan untuk mengetahui apakah sampel berasal dari populasi yang berdistribusi normal atau tidak. Untuk menguji normalitas digunakan metode Lilliefors. Rangkuman hasil uji normalitas pada setiap kelompok disajikan berikut ini:

Tabel 5. Hasil Uji Normalitas Prestasi

\begin{tabular}{lllll}
\hline Kelompok & Sig & A & Keputusan Uji & Kesimpulan \\
\hline Eksperimen 1 (Scientific) & 0,305 & 0,05 & $\mathrm{H}_{0}$ diterima & Berdistribusi Normal \\
\hline Eksperimen 2 (PMRI) & 0,196 & 0,05 & $\mathrm{H}_{0}$ diterima & Berdistribusi Normal \\
\hline Kontrol (Langsung) & 0,503 & 0,05 & $\mathrm{H}_{0}$ diterima & Berdistribusi Normal \\
\hline Kemandirian Belajar Tinggi & 0,186 & 0,05 & $\mathrm{H}_{0}$ diterima & Berdistribusi Normal \\
\hline Kemandirian Belajar Sedang & 0,547 & 0,05 & $\mathrm{H}_{0}$ diterima & Berdistribusi Normal \\
\hline Kemandirian Belajar Rendah & 0,199 & 0,05 & $\mathrm{H}_{0}$ diterima & Berdistribusi Normal \\
\hline
\end{tabular}

(Sumber: Data Primer, Tahun: 2017) 
Berdasarkan keputusan uji tersebut, maka dapat disimpulkan bahwa data pada setiap sampel berasal dari populasi yang berdistribusi normal.

Tabel 6. Hasil Uji Normalitas Minat

\begin{tabular}{lllll}
\hline Kelompok & Sig & A & Keputusan Uji & Kesimpulan \\
\hline Eksperimen 1 (Scientific) & 0,234 & 0,05 & $\mathrm{H}_{0}$ diterima & Berdistribusi Normal \\
\hline Eksperimen 2 (PMRI) & 0,117 & 0,05 & $\mathrm{H}_{0}$ diterima & Berdistribusi Normal \\
\hline Kontrol (Langsung) & 0,107 & 0,05 & $\mathrm{H}_{0}$ diterima & Berdistribusi Normal \\
\hline Kemandirian Belajar Tinggi & 0,340 & 0,05 & $\mathrm{H}_{0}$ diterima & Berdistribusi Normal \\
\hline Kemandirian Belajar Sedang & 0,075 & 0,05 & $\mathrm{H}_{0}$ diterima & Berdistribusi Normal \\
\hline Kemandirian Belajar Rendah & 0,072 & 0,05 & $\mathrm{H}_{0}$ diterima & Berdistribusi Normal \\
\hline
\end{tabular}

(Sumber: Data Primer, Tahun: 2017 )

Berdasarkan keputusan uji tersebut, maka dapat disimpulkan bahwa data pada setiap sampel berasal dari populasi yang berdistribusi normal.

2) Uji Homogenitas Variansi

Uji homogenitas variansi dilakukan dengan tujuan untuk mengetahui apakah populasi mempunyai variansi yang sama. Uji homogentias variansi yang digunakan adalah uji Bartlett dengan statistik uji chi kuadrat. Berikut ini disajikan rangkuman hasil uji homogenitas variansi pada setiap pasangan kelompok:

Tabel 7. Hasil Uji Homogenitas Variansi Prestasi

\begin{tabular}{lllll}
\hline Kelompok & Sig & $\boldsymbol{\alpha}$ & $\begin{array}{l}\text { Keputusan } \\
\text { Uji }\end{array}$ & Kesimpulan \\
\hline $\begin{array}{l}\text { Eksperimen 1 (Scientific), eksperimen } \\
\text { (PMRI), dan kontrol (langsung) }\end{array}$ & 0,079 & 0,05 & $H_{0}$ diterima & $\begin{array}{l}\text { Variansi } \\
\text { Homogen }\end{array}$ \\
\hline $\begin{array}{l}\text { Kemandirian belajar tinggi, sedang, } \\
\text { dan rendah }\end{array}$ & 0,101 & 0,05 & $H_{0}$ diterima & $\begin{array}{l}\text { Variansi } \\
\text { Homogen }\end{array}$ \\
\hline
\end{tabular}

(Sumber: Data Primer, Tahun: 2017)

Berdasarkan keputusan uji tersebut, maka dapat disimpulkan bahwa ketiga kelompok mempunyai variansi yang homogen.

Tabel 8. Hasil Uji Homogenitas Variansi Minat

\begin{tabular}{|c|c|c|c|c|}
\hline Kelompok & Sig & $\alpha$ & $\begin{array}{l}\text { Keputusan } \\
\text { Uji }\end{array}$ & Kesimpulan \\
\hline $\begin{array}{l}\text { Eksperimen } 1 \text { (Scientific), eksperimen } \\
2 \quad \text { (PMRI), dan kontrol (langsung) }\end{array}$ & 0,986 & 0,05 & $H_{0}$ diterima & $\begin{array}{l}\text { Variansi } \\
\text { Homogen }\end{array}$ \\
\hline $\begin{array}{l}\text { Kemandirian belajar tinggi, sedang, } \\
\text { dan rendah }\end{array}$ & 0,214 & 0,05 & $H_{0}$ diterima & $\begin{array}{l}\text { Variansi } \\
\text { Homogen }\end{array}$ \\
\hline
\end{tabular}

(Sumber: Data Primer, Tahun: 2017)

Berdasarkan keputusan uji tersebut, maka dapat disimpulkan bahwa ketiga kelompok mempunyai variansi yang homogen. 
Histogram: Jurnal Pendidikan Matematika, 2 (2), 2018 - 90

Annis Deshinta Ayuningtyas, Dafid Slamet Setiana

b. Uji Analisis Variansi (ANAVA) Prestasi

Penelitian ini menggunakan uji hipotesis dengan analisis variansi dua jalan dengan sel tidak sama. Berikut ini disajikan rangkuman hasil uji analisis variansi dua jalan:

Tabel 9. Rangkuman Hasil Uji Analisis Variansi Dua Jalan Prestasi

\begin{tabular}{llll}
\hline Sumber & Sig & $\boldsymbol{\alpha}$ & Keputusan Uji \\
\hline Pendekatan (A) & 0,000 & 0,05 & $\mathrm{H}_{0 \mathrm{~A}}$ ditolak \\
\hline Kemandirian Belajar (B) & 0,001 & 0,05 & $\mathrm{H}_{0 \mathrm{~B}}$ ditolak \\
\hline Interaksi (AB) & 0,250 & 0,05 & $\mathrm{H}_{0 \mathrm{AB}}$ diterima \\
\hline
\end{tabular}

(Sumber: Data Primer, Tahun: 2017)

Dari hasil rangkuman analisis variansi dua jalan pada tabel 9 di atas ditunjukkan bahwa:

1) Untuk pendekatan pembelajaranberdasarkan keputusan uji tersebut, dapat disimpulkan bahwa ada perbedaan efek antara pendekatan pembelajaran terhadap prestasi belajar. Dengan kata lain, pendekatan pembelajaran scientific, pendekatan pembelajaran PMRI dan pembelajaran langsung mempunyai prestasi yang berbeda.

2) Untuk kemandirian belajar berdasarkan keputusan uji tersebut, dapat disimpulkan bahwa ada perbedaan efek antara kemandirian belajar mahasiswa terhadap prestasi belajar mahasiswa. Dengan kata lain, mahasiswa dengan kemandirian belajar tinggi, sedang, dan rendah mempunyai prestasi belajar yang berbeda.

3) Untuk interaksi berdasarkan keputusan uji tersebut, tidak ada interaksi antara pendekatan pembelajaran dan kemandirian belajar terhadap prestasi belajar mahasiswa. Dengan kata lain, pendekatan pembelajaran tidak berpengaruh terhadap prestasi belajar mahasiswa bergantung pada kemandirian belajar mahasiswa.

c. Uji Lanjut Pasca Anava Prestasi

Berdasarkan hasil uji ANAVA, keputusan uji $\mathrm{H}_{0 \mathrm{~A}}$ ditolak. Hal ini berarti pendekatan pembelajaran Scientific, pendekatan pembelajaran PMRI dan pembelajaran langsung memberikan efek yang berbeda terhadap prestasi belajar. Untuk mengetahui perbedaannya dilakukan komparasi ganda antar baris. Berikut ini disajikan rangkuman komparasi ganda antara baris:

Tabel 10. Rangkuman Komparasi Ganda Antar Baris

\begin{tabular}{clll}
\hline $\mathbf{H}_{\mathbf{O}}$ & $\mathbf{S i g}$ & $\boldsymbol{\alpha}$ & Keputusan Uji \\
\hline$\mu_{1 .}=\mu_{2 .}$ & 0,148 & 0,05 & $\mathrm{H}_{0}$ diterima \\
\hline$\mu_{1 .}=\mu_{3 .}$ & 0,000 & 0,05 & $\mathrm{H}_{0}$ ditolak \\
\hline$\mu_{2 .}=\mu_{3 .}$ & 0,027 & 0,05 & $\mathrm{H}_{0}$ ditolak \\
\hline
\end{tabular}

(Sumber: Data Primer, Tahun: 2017) 
Dari rangkuman komparasi ganda antar baris pada Tabel 10 diperoleh hasil sebagai berikut:

1) Untuk penerapan pendekatan pembelajaran Scientific dan PMRIberdasarkan keputusan uji tersebut, pendekatan pembelajaran Scientific memberikan prestasi belajar yang sama dengan PMRI.

2) Untuk penerapan pendekatan pembelajaran Scientific dan pembelajaran langsung berdasarkan keputusan uji tersebut, pendekatan pembelajaran Scientific berbeda prestasi belajarnya dengan pembelajaran langsung.

3) Untuk penerapan pendekatan pembelajaran Scientific dan pembelajaran langsung berdasarkan keputusan uji tersebut, pendekatan pembelajaran Scientific berbeda prestasi belajarnya dengan pembelajaran langsung.

Berdasarkan hasil uji ANAVA, keputusan uji $\mathrm{H}_{0 \mathrm{~B}}$ ditolak. Hal ini berarti mahasiswa dengan kemandirian belajar tinggi, sedang, dan rendah mempunyai prestasi belajar yang berbeda. Untuk mengetahui perbedaannya dilakukan komparasi ganda antar kolom. Berikut ini disajikan rangkuman komparasi ganda antara kolom:

Tabel 11. Rangkuman Komparasi Ganda Antar Kolom

\begin{tabular}{clll}
\hline $\mathbf{H}_{\mathbf{O}}$ & Sig & $\boldsymbol{\alpha}$ & Keputusan Uji \\
\hline$\mu_{.1}=\mu_{.2}$ & 0,890 & 0,05 & $\mathrm{H}_{0}$ diterima \\
\hline$\mu_{.1}=\mu_{.3}$ & 0,004 & 0,05 & $\mathrm{H}_{0}$ ditolak \\
\hline$\mu_{.2}=\mu_{.3}$ & 0,005 & 0,05 & $\mathrm{H}_{0}$ ditolak \\
\hline
\end{tabular}

(Sumber: Data Primer, Tahun: 2017)

Dari rangkuman komparasi ganda antar kolom pada Tabel 11 diperoleh hasil sebagai berikut:

1) Berdasarkan keputusan uji tersebut, mahasiswa dengan kemandirian belajar tinggisama prestasi belajarnya dengan siswa yang mempunyai kemandirian sedang.

2) Berdasarkan keputusan uji tersebut, mahasiswa dengan kemandirian belajar tinggi berbeda prestasi belajarnya dengan siswa yang mempunyai kemandirian rendah.

3) Berdasarkan keputusan uji tersebut, siswa dengan kemandirian belajar sedang berbeda prestasi belajarnya dengan siswa yang mempunyai kemandirian rendah.

Berdasarkan hasil uji ANAVA, keputusan uji $\mathrm{H}_{0 \mathrm{AB}}$ diterima. Hal ini berarti tidak ada interaksi antara pendekatan pembelajaran dan kemandirian belajar terhadap prestasi belajar. Dengan kata lain, pendekatan pembelajaran tidak berpengaruh terhadap prestasi belajar bergantung pada kemandirian belajar mahasiswa. 
Histogram: Jurnal Pendidikan Matematika, 2 (2), 2018 - 92

Annis Deshinta Ayuningtyas, Dafid Slamet Setiana

d. Uji Analisis Variansi (ANAVA) Minat

Penelitian ini menggunakan uji hipotesis dengan analisis variansi dua jalan dengan sel tidak sama. Berikut ini disajikan rangkuman hasil uji analisis variansi dua jalan:

Tabel 12. Rangkuman Hasil Uji Analisis Variansi Dua Jalan Minat

\begin{tabular}{llll}
\hline Sumber & Sig & $\boldsymbol{\alpha}$ & Keputusan Uji \\
\hline Pendekatan (A) & 0,913 & 0,05 & $\mathrm{H}_{0 \mathrm{~A}}$ diterima \\
\hline Kemandirian Belajar (B) & 0,423 & 0,05 & $\mathrm{H}_{\mathrm{OB}}$ diterima \\
\hline Interaksi (AB) & 0,635 & 0,05 & $\mathrm{H}_{0 \mathrm{AB}}$ diterima \\
\hline
\end{tabular}

(Sumber: Data Primer, Tahun: 2017)

Dari hasil rangkuman analisis variansi dua jalan pada tabel 12 di atas ditunjukkan bahwa:

1) Untuk pendekatan pembelajaranberdasarkan keputusan uji tersebut, dapat disimpulkan bahwa tidak ada perbedaan efek antara pendekatan pembelajaran terhadap minat belajar. Dengan kata lain, pendekatan pembelajaran scientific, pendekatan pembelajaran PMRI dan pembelajaran langsung mempunyai minat belajar yang sama.

2) Untuk kemandirian belajar berdasarkan keputusan uji tersebut, dapat disimpulkan bahwa tidak ada perbedaan efek antara kemandirian belajar mahasiswa terhadap minat belajar mahasiswa. Dengan kata lain, mahasiswa dengan kemandirian belajar tinggi, sedang, dan rendah mempunyai minat belajar yang sama.

3) Untuk interaksi berdasarkan keputusan uji tersebut, tidak ada interaksi antara pendekatan pembelajaran dan kemandirian belajar terhadap minat belajar mahasiswa. Dengan kata lain, pendekatan pembelajaran tidak berpengaruh terhadap minat belajar mahasiswa bergantung pada kemandirian belajar mahasiswa.

\section{B. PEMBAHASAN}

Dalam penelitian ini, diterapkan pendekatan pembelajaran Scientific, PMRI, dan Langsung pada materi metode simpleks. Beberapa hal yang diteliti diantaranya pengaruh pendekatan pembelajaran terhadap prestasi dan minat belajar, pengaruh kemandirian belajar terhadap prestasi dan minat belajar, dan interaksi antara pendekatan pembelajaran dengan kemandirian belajar. Berikut ini akan disampaikan pembahasan dari masalah yang telah diteliti.

1. Prestasi Belajar Matematika

a. Pengaruh Pendekatan Pembelajaran Terhadap Prestasi Belajar 


\section{Histogram: Jurnal Pendidikan Matematika, 2 (2), 2018 - 93 Annis Deshinta Ayuningtyas, Dafid Slamet Setiana}

Berdasarkan uji anava diperoleh hasil bahwa hipotesis nol $\left(\mathrm{H}_{0 \mathrm{~A}}\right)$ yang menyatakan "tidak ada perbedaan pengaruh pendekatan pembelajaran terhadap variabel terikat" ditolak. Ini berarti bahwa terdapat perbedaan prestasi belajar antara mahasiswa yang diberi pembelajaran dengan pendekatan scientifik pendekatan PMRI dan pendekatan pembelajaran langsung. Selanjutnya berdasarkan uji lanjut pasca anava diperoleh hasil bahwa prestasi belajar mahasiswa yang diberi pembelajaran dengan pendekatanscientifik memiliki prestasi yang sama baikdengan mahasiswa yang diberi pembelajaran dengan pendekatan PMRI.

Prestasi belajar mahasiswa yang diberi pembelajaran dengan pendekatanscientifik memiliki prestasi yang lebih baikdaripada mahasiswa yang diberi pembelajaran dengan pendekatanpembelajaran langsung. Hal ini disebabkan karena pendekatan pembelajaran scientifik memiliki beberapa kriteria diantaranya (1) mendorong dan menginspirasi siswa berpikir secara kritis, analistis, dan tepat dalam mengidentifikasi, memahami, memecahkan masalah, dan mengaplikasikan materi pembelajaran; (2) mendorong dan menginspirasi siswa mampu berpikir hipotetik dalam melihat perbedaan, kesamaan, dan tautan satu sama lain dari materi pembelajaran; (3) mendorong dan menginspirasi siswa mampu memahami, menerapkan, dan mengembangkan pola berpikir yang rasional dan objektif dalam merespon materi pembelajaran; serta (4) Berbasis pada konsep, teori, dan fakta empiris yang dapat dipertanggungjawabkan (Kemendikbud, 2013). Dengan demikian metode scientifik memberi dampak positif terhadap prestasi belajar matematika.

Prestasi belajar mahasiswa yang diberi pembelajaran dengan pendekatanPMRI memiliki prestasi yang lebih baikdaripada mahasiswa yang diberi pembelajaran dengan pendekatanpembelajaran langsung. Hal ini disebabkan karena pendekatan PMRImengaitkan materi pelajaran yang dipelajari siswa dengan situasi dunia nyata. Siswa akan didorong untuk membuat hubungan antara pengetahuan yang mereka konstruksi sendiri ketika belajar dengan penerapannya dalam kehidupan mereka sehari-hari sehingga terjadi kebermaknaan dalam belajar yang hal ini dapat memudahkan siswa untuk memahami suatu konsep matematika.

b. Pengaruh Kemandirian Belajar Terhadap Prestasi Belajar

Berdasarkan uji anava diperoleh hasil bahwa hipotesis nol $\left(\mathrm{H}_{0 \mathrm{~B}}\right)$ yang menyatakan "tidak ada perbedaan pengaruh kemandirian belajar terhadap variabel terikat" ditolak. Ini berarti bahwa terdapat perbedaan prestasi belajar matematika mahasiswa yang memiliki kemandirian belajar tinggi, kemandirian belajar sedang, dan kemandirian belajar rendah. 


\section{Histogram: Jurnal Pendidikan Matematika, 2 (2), 2018 - 94 Annis Deshinta Ayuningtyas, Dafid Slamet Setiana}

Selanjutnya berdasarkan uji lanjut pasca anava diperoleh hasil bahwa mahasiswa yang memiliki kemandirian belajar tinggi dan mahasiswa yang memiliki kemandirian belajar sedang memperoleh prestasi belajar yang relatif sama. Mahasiswa dengan kemandirian belajar tinggi berbeda prestasi belajarnya dengan siswa yang mempunyai kemandirian rendah. Serta mahasiswa dengan kemandirian belajar sedang berbeda prestasi belajarnya dengan siswa yang mempunyai kemandirian rendah.

Perbedaan prestasi belajar disebabkan karena siswa yang memiliki kemandirian belajar dapat memanajemen waktu belajarnya. Hal tersebut sesuai dengan definisi kemandirian belajar yang menyebutkan bahwa kemandirian belajar adalah proses aktif yang dilakukan seseorang untuk mengerjakan sesuatu berdasarkan kemampuan sendiri dengan berinisiatif dalam menyelesaikan masalah tanpa tergantung pada orang lain berdasarkan hasil pengalamannya sendiri dalam interaksi dengan lingkungannya. Selain deinisi tersebut pernyataan yang mendukung aitu pendapat Martinis Yamin (2007:126) yang menyatakan bahwa siswa yang mandiri adalah siswa yang bertanggung jawab, berinisiatif, memiliki keberanian, dan sanggup menerima resiko serta mampu menjadi guru bagi dirinya sendiri yang berarti siswa bisa mengatur kegiatan belajarnya sendiri. Siswa yang mampu mengatur kegiatan belajarnya akan senantiasa memanfaatkan waktunya untuk belajar, dengan demikian prestasi belajar matematikanya akan meningkat.

2. Pengaruh Interaksi antara Pendekatan Pembelajaran dan Kemandirian Belajar Terhadap Prestasi Belajar

Berdasarkan uji anava diperoleh hasil bahwa hipotesis nol $\left(\mathrm{H}_{0 \mathrm{AB}}\right)$ yang menyatakan "tidak ada pengaruh interaksi antara pendekatan pembelajaran dan kemandirian belajar terhadap variabel terikat" diterima. Ini berarti tidak ada interaksi antara pendekatan pembelajaran dan kemandirian belajar matematika mahasiswa terhadap prestasi belajar matematika mahasiswa. Hal ini berarti bahwa pembelajaran dengan menggunakan pendekatan pembelajaran scientifik dan pendekatan pembelajaran PMRI yang menghasilkan prestasi belajar matematika yang lebih baik daripada pendekatan pembelajaran langsung berlaku untuk kelompok mahasiswa yang mempunyai kemandirian belajar tinggi, kemandirian belajar sedang, dan kemandirian belajar rendah.

3. Minat Belajar Matematika Siswa

a. Pengaruh Pendekatan Pembelajaran Terhadap Minat Belajar

Berdasarkan uji anava diperoleh hasil bahwa hipotesis nol $\left(\mathrm{H}_{0 \mathrm{~A}}\right)$ yang menyatakan "tidak ada perbedaan pengaruh pendekatan pembelajaran terhadap variabel terikat" Copyright (c) 2018, Histogram: Jurnal Pendidikan Matematika ISSN: 2549-6700 (print), ISSN 2549-6719 (online) 


\section{Histogram: Jurnal Pendidikan Matematika, 2 (2), 2018 - 95 \\ Annis Deshinta Ayuningtyas, Dafid Slamet Setiana}

diterima. Ini berarti bahwa tidak terdapat perbedaan minat belajar antara mahasiswa yang diberi pembelajaran dengan pendekatan scientifik pendekatan PMRI dan pendekatan pembelajaran langsung.

b. Pengaruh Kemandirian Belajar Terhadap Minat Belajar

Berdasarkan uji anava diperoleh hasil bahwa hipotesis nol $\left(\mathrm{H}_{0 \mathrm{~B}}\right)$ yang menyatakan "tidak ada perbedaan pengaruh pendekatan pembelajaran terhadap variabel terikat" ditolak. Ini berarti bahwa terdapat perbedaan minat belajar matematika mahasiswa yang memiliki kemandirian belajar tinggi, kemandirian belajar sedang, dan kemandirian belajar rendah.

c. Pengaruh Interaksi antara Pendekatan Pembelajaran dan Kemandirian Belajar Terhadap Minat Belajar

Berdasarkan uji anava diperoleh hasil bahwa hipotesis nol $\left(\mathrm{H}_{0 \mathrm{AB}}\right)$ yang menyatakan "tidak ada pengaruh interaksi antara pendekatan pembelajaran dan kemandirian belajar terhadap variabel terikat" diterima. Ini berarti tidak ada interaksi antara pendekatan pembelajaran dan kemandirian belajar matematika mahasiswa terhadap minat belajar matematika. Hal ini berarti bahwa pembelajaran dengan menggunakan pendekatan pembelajaran scientifik, pendekatan pembelajaran PMRI, dan pendekatan pembelajaran langsung menghasilkan minat belajar matematika yang sama berlaku untuk kelompok mahasiswa yang mempunyai kemandirian belajar tinggi, kemandirian belajar sedang, dan kemandirian belajar rendah.

\section{KESIMPULAN DAN SARAN}

\section{A. Kesimpulan}

Berdasarkan kajian teori dan hasil analisis dapat ditarik kesimpulan sebagai berikut

1. Pembelajaran dengan pendekatan pembelajaranscientifik menghasilkan prestasi belajar matematika yang lebih baik jika dibandingkan dengan pendekatan pembelajaran langsung.

2. Pembelajaran dengan pendekatan PMRI menghasilkan prestasi belajar matematika yang lebih baik jika dibandingkan dengan pendekatan pembelajaran langsung.

3. Kemandirian belajar berpengaruh terhadap prestasi belajar matematika siswa. Hal ini berarti bahwa siswa yang memiliki kemandirian belajar tinggi, kemandirian belajar sedang, dan kemandirian belajar rendah memiliki prestasi belajar matematika yang berbeda. 
4. Tidak ada interaksi antara pendekatan pembelajaran dengan kemandirian belajar matematika terhadap prestasi belajar matematika.

5. Tidak ada interaksi antara pendekatan pembelajaran dengan kemandirian belajar matematika terhadap minat belajar matematika.

\section{B. Saran}

Berdasarkan kesimpulan dan implikasi di atas, beberapa saran yang peneliti dapat sampaikan yaitu:

1. Pembelajaran dengan pendekatan pembelajaran scientifik dapat dijadikan salah satu alternatif dalam meningkatkan prestasi belajar mahasiswa.

2. Pembelajaran dengan pendekatan pembelajaran PMRI dapat dijadikan salah satu alternatif dalam meningkatkan prestasi belajar mahasiswa.

3. Seorang guru hendaknya mengetahui karakteristik kemandirian belajar masing-masing siswa.

4. Hasil penelitian ini hanya terbatas pada mata kuliah pemrograman linear, sehingga mungkin bisa dicoba diterapkan pada mata kuliah yang lain dengan mempertimbangkan kesesuaiannya.

\section{DAFTAR PUSTAKA}

Anderson, L. (2009). Assessing Affective Characteristics in The Schools. Boston: Allyn and Bacon, Inc.

Budiyono. (2003). Metodologi Penelitian Pendidikan. Surakarta: Sebelas Maret University Press.

Budiyono. (2009). Statistika Untuk Penelitian. Surakarta: Sebelas Maret University Press.

Collete, A. T., \& Chiappeta, E.L. (1994). Science instruction in the middle and secondary schools (3rded). New York: Maccmillan Publishing Company.

Hurlock, E. B. (2002). Child Development Sixth Edition. Jakarta: Erlangga.

Soesarsono. (2004). Pengantar Kewiraswastaan. Bandung: Sinar Baru Algesindo.

Sri Rumini, Nurbadi Yusuf Sukemi, D. Tiala, dan Yulia Ayriza. (2006). Psikologi Pendidikan. Yogyakarta: UNY Press .

Yamin, M. (2007). Desain Pembelajaran Berbasis Tingkat Satuan Pendidikan. Jakarta: Gaung Persada Press. 